\title{
ENGLISH TEACHERS' PERCEPTIONS AND CLASSROOM PRACTICES ON CONSTRUCTIVISM VALUES IN PRIMARY SCHOOLS IN BADUNG REGENCY
}

\author{
N.W.W.Agustini ${ }^{1}$, L.P. Artini ${ }^{2}$, N.N. Padmadewi \\ ${ }^{123}$ English Language Education, Post Graduate Program, Universitas Pendidikan Ganesha, Singaraja \\ e-mail: widyaagustini.niwayan@gmail.com, putu.artini@undiksha.ac.id, nym.padmadewi@undiksha.ac.id
}

This study aimed at: a) describing teachers' perceptions on the concept, implementation, and impact of constructivism values in public primary schools in Badung Regency; b) describing how the teachers practice and implement constructivism values in the classroom; and c) finding out the relation of teachers' perceptions about constructivism values and its practices in the classroom. This study was designed in the form of a mixed methods with the embedded design in which the quantitative data were more dominant than the qualitative data so that the data were described descriptively and quantitatively. The subjects of this study were three English teachers with the same qualifications of educational background (English Education) from three different public primary schools in Badung Regency. The data related to teachers' perceptions were collected through questionnaire administration, the classroom practices and implementation were collected through classroom observations, and supported with interviews. After the data were collected, the data were analyzed quantitatively to analyze the results of the questionnaire, and qualitatively by using interactive analysis model to analyze the results of classroom observations and interviews. The results of the study indicated that: first, the teachers had strong perceptions on the concept, implementation, and impact of constructivism values; second, the frequency of occurrences on the practices of constructivism values in the classroom was categorized as low frequency which indicated that the teachers rarely practiced constructivism values in the classroom; third, since the teachers had strong perceptions on constructivism values but the frequency of the practices was categorized as low frequency. It could be concluded that the teachers tend to be inconsistent between their perceptions on constructivism values with its practices in the classroom.

\section{Keywords: teachers' perceptions, classroom practices, constructivism values}

\section{INTRODUCTION}

Learning a foreign language has been regarded as an important skill for many people since in International level, English is used for communicating, exchanging ideas and concepts. English is considered as a language of opportunity which provides access to knowledge, power and material possessions (Sharma \& Poonam, 2016). Thus, in this globalization era, it is important to introduce English to the learners in early stages of their lives. Zein (2015) states that the failure of the teaching of English in secondary schools is the main reason for pushing early English instruction. Therefore, teaching English in early age is necessary in order to prepare them to compete on the next level of their life and education. It is expected that English instruction at elementary level contributes to the development of students' overall language competence (Sadtono in Zein, 2015).

Many countries around the world have government policy to introduce English in primary schools at an earlier age with significant effects on English language learning and teaching practices (Copland, et al., 2014). The presence of English in primary schools is a must in order to prepare the learners for the future competitions (Putra, 2012). Chaves (in Sarem \& Hamidi, 2012) states that when individuals learn a second or foreign language when they are young, and they learn it from the native speakers, they will be able to speak it naturally, with their own accent. It is also believed that learning English in early stages gives advantages since children are able to learn faster and understand things easier than adults (Putra, 2012). 
According to Long; Ara; Damar in Artini (2017), there are two main reasons of the importance to start introducing English as a foreign language in primary schools. First, the young learners are considered more flexible in learning a language (Long; Ara; Damar in Artini, 2017). Young learners are considered to be easier to learn the language since they are more enthusiastic in learning a language (Cameron, 2001). Second, the need of English in society enables the learners to have positive attitudes towards learning the foreign language (Lamb \& Artini in Artini, 2017). Johnstone (in Copland, et al., 2014) also argues that there are three reasons of English being the most commonly introduced in primary school. First, it is assumed that it is better to begin learning languages early. Second, economic globalization has resulted in the widespread use of English and many governments believe it is essential to have English speaking workforce in order to compete. Third, parents want their children to develop English skills to benefit from new world orders and put pressure on governments to introduce English to younger children. Indonesia is the second country after China in terms of the number of children learning English as a foreign language in elementary schools (Zein, 2017). In July 2015, Minister of Ministry of Education and Culture instructed schools to teach three languages, including Indonesian as the national language, a local language of the school's choice, and English as a foreign language (Zein, 2017). Furthermore, Sikki, et al. (2013) argue that as a result of decentralization policy in Indonesia, many districts and city governments are interested in teaching English as a foreign language to young learners. This is evidenced by the increasing number of elementary schools which offer English classes at the elementary schools level. Currently, many elementary schools in Indonesia offer English subject starting at the fourth grade (aged nine to ten), while many other elementary schools even teach English at earlier grades (earlier age). Thus, teaching English before grade four becomes a new trend in Indonesia.

Badung Regency is one of the regencies in Bali Province which offer English as a foreign language in primary schools. According to the Regulation of Badung Regent no. 43 Year 2016, English must be learnt as a foreign language in primary schools in Badung Regency for students from the first until the sixth grade. Furthermore, according to the regulation, the purposes of teaching English as a foreign language in primary schools are: 1) to enable students to communicate effectively with the proper ethics and grammar; 2) to appreciate and use English as a means of communication; 3) to use English to improve students' intellectual, emotional, and social ability; and 4) to use English in International relation and context. In order to reach these goals, several things need to be considered, such as teachers, students, learning materials, and settings or learning environments (Noni, 2016). Qualified and competent teachers, appropriate learning materials, interesting teaching and learning process, and enjoyable learning environment are necessary in order to reach these goals.

In order to teach English as a foreign language in primary schools successfully, qualified and competent teachers are needed. Sikki, et al. (2013) believe that all teachers who teach English to young learners should understand the theories of language acquisition in general and the child second language acquisition in particular, bilingualism and the literacy skills in the early years. They also should know theories of multiple intelligence, total physical response, left and right brain learning, formulaic language and work with songs and how to exploit and use of learning structures, vocabulary and facilitate pronunciation. In addition, Musthafa (in Noni, 2016) elaborates five pillars that English teachers should know, including 1) the children they teach, 2) how children learn, 3) how children learn language, 4) how Indonesian children learn English as a foreign language, and 5) how to facilitate children to learn English as a foreign language in Indonesia.

There are two kinds of elementary English teachers in Indonesia, namely generalist and specialist teachers (Zein, 2017). Generalist teachers are the teachers who graduated from Primary School Teacher Education in which they have acquired knowledge and skills related to teach young learners, approaches and methods of teaching, educational philosophies, teaching practicum, testing and assessment, but their exposure to English is limited since they are only provided with basic English proficiency (Suyanto in Zein, 2015). On the other hand, specialist teachers are the teachers who graduated from English Language Education 
in which they have acquired strong English language proficiency, and knowledge and skills related to curriculum, syllabus, language testing and assessment, teaching methodologies, teaching skills, and material development (Zein, 2015). Zein (2017) also argues that the generalist teachers teach English to children in their own classroom and generally they have low English proficiency, while specialist teachers teach English to children across grade, from the first until the sixth grade, and generally they have low to high English proficiency.

Sikki, et al. (2013) argue that English teachers' competencies in primary school need to be improved. In their research, they found that more than $50 \%$ teachers have poor and fair professional competency, and $90.5 \%$ teachers have poor and fair pedagogic competence. Sukamerta (in Noni, 2016) states that most of the teachers who taught English at primary school did not have adequate English language competence and skills in order to be teachers of English as a foreign language at primary school, since some of them did not have English education background. Zein (2017) also states that generalist teachers implement traditional approaches in which they read aloud or dictate the content of a book and ask the children to repeat, then they write on the board and ask the students to copy. This approach is inappropriate with young learners' characteristics since it does not involve students' instinct for playing and having fun and it does not enable students to have lively imagination. In addition, Copland, et al. (2014) report that teachers are challenged partly by lack of training, lack of knowledge, and lack of resources. Other challenges are including class size, teachers' own skills and confidence in English, and time pressures. Kumaravadivelu (in Copland, et al., 2014) argues that teachers should be helped to develop the knowledge and skill, attitude, and autonomy necessary to construct their own pedagogic knowledge. Thus, teachers need to improve their competencies and implement appropriate approach and strategy that suit students' characteristics as young learners.

The current curriculum implemented in schools in Indonesia is curriculum 2013. In curriculum 2013, the teaching and learning process at classroom should be interactive, inspirative, enjoyable, challenging, and be able to motivate the learners to be active participants, and give them opportunity to develop their initiative, creativity, and independence based on their interest and talent (Suharyadi, 2013). In other words, curriculum 2013 emphasizes on students centered. Students are expected to actively learn by doing and construct knowledge by themselves rather than they are given material by the teacher. Teaching students with the notion of critical thinking and problem solving skills is one of the main principles of curriculum 2013. Moreover, the teaching activity should be developed to educate students to be able to inquire and solve problems that they face. Thus, teachers should be able to choose the appropriate approach and strategies in order to reach the goals of the teaching and learning process in the classroom.

Many countries emphasize on the trend of moving away from a knowledge-based, examination-driven system to a students-centred, performance-driven system ( $\mathrm{Li}, 2012)$. The problem lies in the learning environment in a conventional classrooms is the classroom environment is teacher centered which makes learning process boring for less competent students. Students lost their focus and attention frequently and they are not able to receive the information for long time period and are often caught daydreaming, talking and disturbing other students (Dagar \& Yadav, 2016). A system where learners receive all information as ready from the teacher is considered inadequate, but instead, it is necessary to pass a system where the learners are active in their educational environment, configurate the old information in mind with new information, and use this information in order to produce new information. The individual differences existing between learners, their background knowledge and learning styles are also often ignored in the conventional classrooms (Dagar \& Yadav, 2016). Because of this necessity, many countries change their traditional education system and adopt the constructivism learning (Ayaz \& Sekerci, 2015).

Currently, constructivism is the most supported learning theory to language learning and its main contribution to educational psychology is the learner-centred approach, which emphasizes the autonomy of learners in the process of their education (Aljohani, 2017). Constructivism is a theory about teaching and learning which involves essential aspects such as culture, context, literacy, language, learners' interests and needs, personal experiences, 
interpretation of reality, as well as application of knowledge (Mogashoa, 2014). Constructivism shares a focus on the learners-centred approach and the value of providing the learners with opportunities to make meaning and be real dynamic contributors in the learning-teaching experience. Furthermore, constructivism believes that knowledge is constructed, involving social processes, interaction with the environment and self-reflection, required a great resource frame work, in that they encourage learner centered experiences, provide opportunities for learners to work together, encourages individuals to make sense of information for themselves, focuses on the role of social interaction (Bhutto \& Chhapra, 2013). Constructivism is more focused on innovative activities and knowledge acquisition and therefore, the academic results of the students of constructivism classrooms are better than traditional classrooms (Dagar \& Yadav, 2016). Teachers need to reflect on their practice in order to apply these ideas to their work and that constructivism teachers encourage students to constantly assess how the activity is helping them gain understanding (Bada, 2015).

Constructivism is a theory of learning that human learning is constructed, that learners build new knowledge upon the foundation of the previous learning (Bada, 2015). Constructivism learning theory root the constructivistic pedagogical approach and then it details into constructivism values to make it applicable in the learning process in the classroom in which the main values of constructivism are knowledge is constructed from learners' experiences and the learner is an active creator (Amarin \& Ghishan, 2013; Sharma \& Poonam, 2016; Aljohani, 2017). Thus, in this study, constructivism value is the components of constructivism that transferable and observable in the process of teaching and learning process in the classroom. Constructivism comprises several values including language teaching is action orientedness (Aljohani, 2017), enable students to construct knowledge (Amarin \& Ghishan, 2013; Bada, 2015), teachers are facilitators (Weegar \& Pacis, 2012), students are active and autonomous learners (Aljohani, 2017), use various learning sources and learning media (Bada, 2015; Bhattacharjee, 2015; Dagar and Yadav, 2016), involve students' higher order thinking and problem solving skills (Giridharan, 2012), use contextual learning (Sharma \& Poonam, 2016; Dagar and Yadav, 2016), dominated by collaborative learning style (Dagar and Yadav, 2016), give students ownership of what they learn (Bada, 2015) and promote social and communication skills by creating a classroom environment that emphasizes collaboration (Bada, 2015).

There are numerous studies that investigate the effectiveness of constructivism values in the classroom. However, there has been a lack of study on describing teachers' perceptions and classroom practices of constructivism values in teaching English as a foreign language in public primary schools in Badung Regency. In addition, the relation of teachers' perceptions about constructivism values and its classroom practices in teaching English as a foreign language in the classroom is also rarely found in the researches. Therefore, this study is conducted in order to describe teachers' perceptions and classroom practices on constructivism values in teaching English as a foreign language in public primary schools in Badung Regency. This study also aimed at finding out the relation of teachers' perceptions about constructivism values and its practices in teaching English as a foreign language in the classroom

\section{RESEARCH METHOD}

This study was designed in the form of a mixed methods design with the embedded design in which the quantitative data were more dominant than the qualitative data. According to Creswell (2012), a mixed method research design was a procedure used for collecting, analyzing, and mixing both qualitative and quantitative methods in a single study or a series of studies to understand a research problem. The embedded design is a mixed methods design in which one data set provided a supportive, secondary role in a study based primarily on the other data type (Creswell \& Plano, 2011). The subjects of this study were three English teachers with the same qualifications of educational background (English Education) from three different primary schools in Badung Regency. The data related to teachers' perceptions were collected through questionnaire administration, the classroom 
practices and implementation were collected through classroom observations, and supported with interviews. The instruments used in this study were questionnaire, observation sheet, and interview guide. Furthermore, after the data were collected, the data were analyzed quantitatively to analyze the results of the questionnaire, and qualitatively by using interactive analysis model to analyze the results of classroom observations and interviews

\section{FINDINGS AND DISCUSSION}

Referring to the results of the questionnaire, it was showed that overall the teachers had strong perceptions on the concept, implementation, and impact of constructivism values. The average range of teachers' perceptions on concept of constructivism was 3.88, the average range of teachers' perceptions on the implementation of constructivism was 3.49, and the average range of teachers' perceptions on the impact of constructivism was 3.58. All of them were in interval $3.3335 \leq M \geq 4.0005$ which categorized high and the qualification was strong. It indicated that the subject teachers had strong perceptions on constructivism values. They very strongly believed that language teaching was action orientedness. They also strongly agreed that it was important to enable students to construct knowledge, teachers were facilitators, students were active and autonomous learners, it was important to use various learning sources and learning media, it was significantly needed to use contextual learning, it was important to give ownership to students of what they learnt and it was necessary to promote social and communication skills by creating a classroom environment that emphasizes collaboration. However, they had moderately strong perceptions on 2 components in the implementation of constructivism values in which it was about involving students' higher order thinking skill and problem solving skill and also dominated learning process by collaborative learning style.

According to the results of classroom observations, it could be seen that the values of constructivism were not dominantly implemented in the classroom by the teachers. The highest percentage was on the third values in which teachers were facilitators. It indicated that the teachers have become good facilitators during the teaching and learning process. Furthermore, other components that were implemented the most in the classroom by the subject teachers were students were active and autonomous learners, and using contextual learning. It indicated that the teachers gave opportunity for students to be active learners by providing activities and tasks that involved students' participation. Moreover, the teachers were also able to relate the materials with students' daily life in which it made the materials and the learning process became more meaningful. Sometimes, the teachers used learning media, such as video, picture, songs and game in the classroom in which it could build positive learning environment and it made the learning process became more fun and enjoyable. However, the teachers rarely provided activities that were dominated by collaborative learning style since most of the learning activities and tasks were done individually. Only few students who did small discussion in doing the task. Moreover, due to the teachers rarely created a classroom environment that emphasized on collaboration, the students had less opportunities to promote social and communication skills. They rarely did social negotiation in sharing ideas from multiple perspectives since they rarely did the tasks in group. The teachers also rarely provided activities and tasks that involved students' higher order thinking skill and problem solving skill. They mostly provided activities and tasks that were easy for the students in which it did not improve students' ability in higher order thinking skill and problem solving skill. Thus, only few of values of constructivism which were implemented in the classroom by the teachers.

Since the teachers had strong perceptions about constructivism values but the frequency of implementation of constructivism values in the classroom was low, it could be concluded that the teachers were inconsistent between their perceptions about constructivism values and its practices in the classroom. Among 10 values of constructivism, the teachers had good consistency in 3 values, slightly consistent in 1 values, lack consistent in 2 values, inconsistent in 3 values and strongly inconsistent in 1 values. It indicated that they consistently implemented $30 \%$ of constructivism values and inconsistently implemented 
$70 \%$ of constructivism values. The specific results of the relation of teachers' perceptions and its classroom practices could be seen on Table 1

Tabel 1. The relation of teachers' perceptions and its classroom practices

\begin{tabular}{|c|c|c|c|c|c|}
\hline \multirow[b]{2}{*}{ Domain } & \multirow{2}{*}{$\begin{array}{l}\text { Constructivism } \\
\text { Values }\end{array}$} & \multicolumn{2}{|c|}{$\begin{array}{l}\text { Teachers' } \\
\text { Perceptions }\end{array}$} & \multicolumn{2}{|c|}{$\begin{array}{l}\text { Implementation } \\
\text { (Frequency) }\end{array}$} \\
\hline & & $\begin{array}{c}\text { Average } \\
\text { Range of } \\
\text { Perceptions }\end{array}$ & Category & $\begin{array}{l}\text { Average } \\
\text { Range of } \\
\text { Frequency }\end{array}$ & Category \\
\hline \multirow[t]{2}{*}{$\begin{array}{l}\text { Concept of } \\
\text { Constructivism }\end{array}$} & $\begin{array}{l}\text { Language } \\
\text { teaching is action } \\
\text { orientedness. }\end{array}$ & 4.17 & $\begin{array}{l}\text { Very } \\
\text { Strong }\end{array}$ & 4 & $\begin{array}{l}\text { Very Low } \\
\text { Frequency }\end{array}$ \\
\hline & $\begin{array}{l}\text { Enable students } \\
\text { to construct } \\
\text { knowledge. }\end{array}$ & 3.58 & Strong & 10 & $\begin{array}{l}\text { Moderate } \\
\text { Frequency }\end{array}$ \\
\hline \multirow{6}{*}{$\begin{array}{l}\text { Implementation } \\
\text { of } \\
\text { Constructivism }\end{array}$} & $\begin{array}{l}\text { Teachers are } \\
\text { facilitators. }\end{array}$ & 3.83 & Strong & 17.67 & $\begin{array}{l}\text { Very High } \\
\text { Frequency }\end{array}$ \\
\hline & $\begin{array}{l}\text { Students are } \\
\text { active and } \\
\text { autonomous } \\
\text { learners. }\end{array}$ & 3.33 & Strong & 11 & $\begin{array}{l}\text { High } \\
\text { Frequency }\end{array}$ \\
\hline & $\begin{array}{l}\text { Use various } \\
\text { learning sources } \\
\text { and learning } \\
\text { media. }\end{array}$ & 3.67 & Strong & 5 & $\begin{array}{l}\text { Very Low } \\
\text { Frequency }\end{array}$ \\
\hline & $\begin{array}{l}\text { Involve students' } \\
\text { higher order } \\
\text { thinking skill and } \\
\text { problem solving } \\
\text { skill. }\end{array}$ & 3.08 & $\begin{array}{l}\text { Moderately } \\
\text { Strong }\end{array}$ & 2 & $\begin{array}{l}\text { Very Low } \\
\text { Frequency }\end{array}$ \\
\hline & $\begin{array}{l}\text { Use contextual } \\
\text { learning. }\end{array}$ & 3.87 & Strong & 11 & $\begin{array}{l}\text { High } \\
\text { Frequency }\end{array}$ \\
\hline & $\begin{array}{l}\text { Dominated by } \\
\text { collaborative } \\
\text { learning style. }\end{array}$ & 3.17 & $\begin{array}{l}\text { Moderately } \\
\text { Strong }\end{array}$ & 1.33 & $\begin{array}{l}\text { Very Low } \\
\text { Frequency }\end{array}$ \\
\hline \multirow[t]{2}{*}{$\begin{array}{l}\text { Impact of } \\
\text { Constructivism }\end{array}$} & $\begin{array}{l}\text { Give students } \\
\text { ownership of what } \\
\text { they learn. }\end{array}$ & 3.33 & Strong & 4.33 & $\begin{array}{l}\text { Very Low } \\
\text { Frequency }\end{array}$ \\
\hline & $\begin{array}{l}\text { Promote social } \\
\text { and } \\
\text { communication } \\
\text { skills by creating a } \\
\text { classroom } \\
\text { environment that } \\
\text { emphasizes } \\
\text { collaboration. }\end{array}$ & 3.83 & Strong & 1.67 & $\begin{array}{l}\text { Very Low } \\
\text { Frequency }\end{array}$ \\
\hline
\end{tabular}

The results showed that the teachers were consistent in 3 values, namely teachers are facilitators, students are active and autonomous learners, and using contextual learning. The teachers always monitored the students during the completion of the task and they also often 
gave feedbacks and reinforcements to the students. It supported the theory proposed by Beyhan, (2013) who stated that teachers' role in a constructivism classroom was to act as an expert learner who could guide the students in constructing and applying knowledge. The teachers could gave opportunities to the students to participate actively in the classroom through singing songs, playing game, or discussing the task in front of the class. It was in accordance with the theory proposed by Dagar \& Yadav (2016) who stated that a constructivist classroom dominantly used students-centered activities. However, even the teachers gave opportunities for students to be active learners, they did not enable students to be autonomous learners who construct knowledge by themselves. Mostly the teachers provided information by the students and just let the students to actively participate in discussing the task or discussing the examples of the materials. The teachers also mostly asked the students to memorize the vocabularies given by the teachers. Thus, it was not in accordance with the theory proposed by Aljohani (2017) who stated that in constructivism, students are encouraged to learn main ideas on their own through discovery learning.

The teachers were slightly consistent to enable students to construct knowledge. The results of classroom observations showed that sometimes the teachers related the material to students' experience or students' prior knowledge in order to give them opportunity to construct knowledge. However, sometimes the teachers provided the materials for the students, especially the vocabularies of the materials. Thus, it was not in accordance with the theory proposed by Marlowe \& Page (in Aljohani, 2017) who stated that one of foundations and values in constructivism was knowledge is constructed, not received. Dagar and Yadav (2016) also believed that the emphasis of constructivism values was knowledge construction rather than knowledge transmission.

The teachers were lack of consistency in 2 values, including involve students' higher order thinking and problem solving skills and also dominated the learning by collaborative learning styles. The teachers very rarely provided activities and tasks which involved students' higher order thinking skill and problem solving skill. They tended to provide easy activities and easy tasks for students. The results of the interview showed the teachers rarely gave activities and tasks that involved students' higher order thinking skill and problem solving skill because the students had lack of ability in higher order thinking and problem solving. The teachers stated that sometimes even the students could not do the easy tasks, so that they thought that it would be difficult for them to do tasks with higher order thinking and problem solving skill. The teachers also stated that mostly they asked the students to memorize English vocabularies in order to enable them to answer English tests. These findings were not in accordance with the theory proposed by Giridharan (2012) who believed that the emphasis in constructivism is on how learners develop skills in logic, solve problems, and follow directions, all of which require higher-order thinking skills. In term of dominated the learning process by collaborative learning style, the results of the classroom observation showed that the teachers rarely provided group work activities for the students since most of the activities and tasks were done individually. Only few students who did small discussion in doing the tasks but they still wrote it individually. The results of the interview revealed that the reasons of the teachers rarely asked the students to work in group were because to avoid some students to dominate the completion of the tasks in group. The teachers wanted all students to do the task without being dominated by some other students. It was likely that the teachers wanted to see students' ability individually rather than their ability in group. Thus, the implementation was not in accordance with the theory proposed by Dagar \& Yadav (2016) who stated that a constructivist classroom should be dominated by collaborative learning style.

The findings showed that teachers were inconsistent in 3 values, namely using various learning sources and learning media, giving students ownership of what they learn, and promoting social and communication skills by creating a classroom environment that emphasize collaboration. In the classroom, the teachers rarely used variations of learning sources and learning media. Sometimes the teachers already used picture, songs, and game as learning media, but the frequency of the use of learning media was very low. In term of learning sources, the teachers only used few learning sources. The teachers also rarely 
asked the students to discover information by themselves in which it caused the students had lack ownership of what they learnt. It was not in accordance with the theory proposed by Bada (2015) who pointed out that one of the benefits of constructivism was it gave students ownership of what they learn, since learning was based on students' questions and explorations. Moreover, the teachers were mostly gave individual task and activities to the students. Lack of group tasks and collaborative learning would cause the students had lack ability in promoting their social and communication skills. The implementation of the teachers in the classroom was not in accordance with the theory proposed by Merill (in Sharma \& Poonam, 2016) who stated that conceptual growth comes from the negotiation of meaning, the sharing of multiple perspectives and the changing of learners' internal representation through collaborative learning. Dagar and Yadav (2016) also believed that in constructivism, learning is enhanced by social interaction.

The teachers were strongly inconsistent on the first value in which it was language teaching was action orientedness. The result of the interview revealed that the teachers mostly asked the students to memorize the vocabularies given rather than apply it into conversation or ask them to do presentation. The teachers stated that it took much times to monitor and guide students if the teachers asked the students to write conversation or to do presentation. It also took much times if students to search information by themselves. The teachers gave lack opportunity for students to learn by doing in which it was not in accordance with the value of constructivism. These findings were not in accordance with the theory proposed by Aljohani (2017) who stated that language teaching is action orientedness and constructivism emphasized on the autonomy of the learners in the process of their education. It was also not in accordance proposed by Bada (2015) who argued that constructivism's central ideas is that learners build new knowledge upon the foundation of the previous learning.

The results of this study revealed that the teachers rarely practiced constructivism values in the classroom in which it is hand to hand to curriculum 2013, the current curriculum implemented at schools. It indicated that the teachers did not implement curriculum 2013 properly at schools. The teachers claimed that it happened because the students had lack of ability in higher order thinking and problem solving skill. The limitation of time also became the reason of why the teachers could not practice constructivism values in the classroom. However, regarding to the results of classroom observations, it seems that teachers' competences in teaching English to young language learners needed to be improved. It was likely that the teachers had lack of preparation in teaching English to the students. Teachers' competencies in developing learning materials also need to be improved. This study revealed that the teachers rarely prepared the materials from various sources since they only focused on the textbook and also small note about the material that they have made. They rarely developed the learning activities to be more challenging in which it could not involve students' higher order thinking and problem solving skills. The teachers also need to improve their creativity in implementing teaching strategy and teaching media in the classroom in order to make the learning process becomes more interesting. Thus, it seems that English teachers in primary schools in Badung Regency need to improve their competencies.

This study revealed that it is likely that English teachers' competencies in primary schools in Badung Regency need to be improved. It supported a study conducted by Sikki, et.al. (2013) who find out that more than $50 \%$ of teachers' professional and pedagogic competences in South Sulawesi are in the category poor and fair which indicate that primary school teachers of English have poor level of professional and pedagogic competences. Professional competence includes teachers' competency in mastering spoken and written English, developing learning material, and utilizing technology information and communication to develop themselves. Meanwhile, pedagogic competence includes teachers' competence in mastering the theory of learning and learning principles, developing curriculum, and using ICT during the learning process. Yulia (2013) also finds that the English teachers in Yogyakarta Province face two main challenges in the classroom, including students' motivation to learn English and teachers' classroom language. She reports that the teachers need to motivate students to learn English by improving their 
teaching techniques and their speaking competence in the classroom to achieve students' integrative motivation. Gunawan \& Suharno (in Zein, 2017) also reports that the majority of teachers in their study in Bandung, West Java, are pedagogically challenged in areas such as classroom management. Therefore, it is recommended to conduct practical professional development for the teachers to improve teachers' competencies in teaching English as a foreign language for young learners.

\section{CONCLUSION AND SUGGESTIONS}

Regarding to the results of the study, it is concluded that the teachers had strong perceptions on the concept, implementation, and impact of constructivism values. It seemed that the teachers had good understanding about the concepts, the implementation, and the impact of constructivism values in the classroom. However, the results of the classroom observations showed different points. The results of classroom observations showed that the teachers rarely implemented the values of constructivism in the classroom. They mostly still used traditional method in the classroom. Sometimes, they gave opportunities for the learners to participate actively during the lesson but they rarely gave opportunities for the learners to construct knowledge by themselves since the teachers mostly provided information needed by the students. Therefore, the relation of teachers' perceptions about constructivism values and its practiced and implementation in the classroom was inconsistent. The results of the interview showed that the inconsistency of the teachers was influenced by several factors such as lack ability of the students in higher order thinking and problem solving skill, the limitation of time, and mostly because the teachers emphasized the learning on vocabularies memorization.

Since the results of the study show that the teachers have strong perceptions on the concept, implementation, and impact of constructivism values, but have low frequency in practicing and implementing it in the classroom, it is suggested for the policy maker in English (school educational practice in general, and English language teaching in particular) to follow up with professional development on practical guidance. It is needed to conduct practical professional development to give opportunity for teachers to do practical guidance and practical example on the practice and implementation of constructivism values in the classroom. It will be beneficial since constructivism is hand to hand to curriculum 2013, the current curriculum implemented at schools.

\section{ACKNOWLEDGEMENT}

The writers' gratitude goes to several parties. First and foremost, the rector and the director of post graduate proram of Ganesha University of Education who facilitated them to accomplish this research. Second, the school principal, supervisors, teachers, and students of GMIS Bali for giving permission to carry out this research.

\section{REFERENCES}

Aljohani, M. (2017). Principles of "Constructivism" in Foreign Language Teaching. Journal of Literature and Art Studies, 7(1), 97-107.

Amarin, N.Z. \& Ghishan, R.I. (2013). Learning with Technology from a Constructivist Point of View. International Journal of Business, Humanities, and Technology, 3(1), 52-57.

Artini, L.P. (2017). Rich Language Learning Environment and Young Learners' Literacy Skills in English. Lingua Cultura, 11(1), 19-24.

Ayaz, M.H. \& Sekerci, H. (2015). The Effects of the Constructivist Learning Approach on Student's Academic Achievement: A Meta-Analysis Study. TOJET: The Turkish Online Journal of Educational Technology, 14(4), 143-156.

Bada, S.O. (2015). Constructivism Learning Theory: A Paradigm for Teaching and Learning. IOSR Journal of Research and Method in Education (IOSR-JRME), 5(6), 66-70. 
Beyhan, O. (2013). The Correlation of Students' Views on Constructivist Teaching Environment and Teachers' Student Control Ideologies. Educational Research and Reviews, 8(9), 553-559.

Bhattacharjee, J. (2015). Constructivist Approach to Learning - An Effective Approach of Teaching Learning. International Research Journal of Interdisciplinary \& Multidisciplinary Studies (IRJIMS), 1(6), 65-74.

Bhutto, S. \& Chhapra, I.U. (2013). Educational Research on "Constructivism" - An Exploratory View. International Journal of Scientific and Research Publications, 3(12).

Cameron, L. (2001). Teaching Language to Young Learners. Cambridge: Cambridge University Press.

Copland, F., \& Garton, S. (2014). Key themes and future directions in teaching English to young learners: introduction to the Special Issue. ELT Journal, 68(3), 223-230.

Creswell, J.W. \& Plano Clark, V.L. (2011). Designing and conducting mixed methods research (2nd ed.). Thousand Oaks, CA: Sage.

Creswell, J.W. (2012). Educational Research Planning, Conducting, and Evaluating Quantitative and Qualitative Research. Fourth Edition. USA: Pearson Education, Inc.

Dagar, V. \& Yadav, A. (2016). Constructivism: A Paradigm for Teaching and Learning. Arts and Social Sciences Journal, 7(4).

Giridharan, B. (2012). Engendering Constructivist Learning in Tertiary Teaching. US-China Education Review A 8, 733-739.

Li, N. (2012). Approaches to learning: Literature review. International Baccalaureate Research Paper.

Mogashoa, T. (2014). Applicability of Constructivist Theory in Qualitative Educational Research. American International Journal of Contemporary Research, 4(7), 51-59.

Noni, N. (2016). Primary School Teachers Perceptions of and Practices in the Selection and Development of English Learning Materials. LITERA Jurnal Penelitian Bahasa, Sastra, dan Pengajarannya, 15(2), 227-238.

Peraturan Bupati Badung Nomor 43 Tahun 2016 tentang Mata Pelajaran Bahasa Inggris sebagai Muatan Lokal untuk Jenjang Pendidikan Sekolah Dasar/Madrasah Ibtidaiyah di Kabupaten Badung. Mangupura: Sekretariat Daerah Kabupaten Badung

Putra, J.R. (2012). Creating a Positive English Language Teaching and Learning Environment in EYL Classroom Setting. Proceeding TEYLIN 2: from policy to classroom, 218-261.

Sarem, S.N. \& Hamidi, H. (2012). A Critical Look at the Available Literature on the Appropriate Time to Start Approaching a Second/Foreign Language. Advances in English Linguistics (AEL), 1(4), 76-79.

Sharma, H.L. \& Poonam. (2016). Constructivist Approach for Teaching English: Making Sense of Paradigm Shift from the Traditional Approach. International Journal of Science and Research, 5(10), 788-792.

Sikki, E.A.A., Rahman, A., Hamra, A., \& Noni, N. (2013). The Competence of Primary School English Teachers in Indonesia. Journal of Education and Practice, 4(11), 139-145.

Suharyadi. (2013). Exploring "Scientific Approach" in English Language Teaching. Paper presented at the National Seminar Exchange of Experiences, Malang. Retrieved from http://teqip.com/wp-content/uploads/2014/03/Kelompok-Bahasa-Inggris-1.pdf

Weegar, M.A. \& Pacis, D. (2012). A Comparison of Two Theories of Learning -- Behaviorism and Constructivism as applied to Face-to-Face and Online Learning. E-Leader Manila. 
Yulia, Y. (2013). Teaching Challenge in Indonesia: Motivating Students and Teachers' Classroom Language. Indonesian Journal of Applied Linguistics, 3(1), 1-16.

Zein, M.S. (2015). Preparing elementary English teachers: Innovations at pre-service level. Australian Journal of Teacher Education, 40(6), 104-120.

Zein, M.S. (2017). Elementary English education in Indonesia: Policy developments, current practices, and future prospects. English Today 129, 33(1), 53-59.

Zein, M.S. (2017). Language-in-Education Policy on Primary EFL: The Case of Indonesia. International Journal of Pedagogies and Learning, 12(2), 133-146. 